\title{
Compelling palatability of protein hydrolysates for Nile tilapia juveniles
}

\author{
Denis Rogério Sanches Alves ${ }^{1,2}$, Thibério Carvalho da Silva ${ }^{1}$, Joana D'arc Maurício Rocha ${ }^{1}$ \\ Suzana Raquel de Oliveira ${ }^{1}$, Altevir Señor ${ }^{1} \&$ Wilson Rogério Boscolo ${ }^{1}$ \\ ${ }^{1}$ Centro de Engenharias e Ciências Exatas, Universidade Estadual do Oeste do Paraná, Toledo, Brasil \\ ${ }^{2}$ Departamento de Engenharia e Exatas, Universidade Federal do Paraná, Palotina, Brasil \\ Corresponding author: Denis Rogério Sanches Alves (drsa6@hotmail.com)
}

\begin{abstract}
This study aimed at determining the compelling palatability of different protein hydrolysates for Nile tilapia juveniles (Oreochromis niloticus). Four isoproteic (30\% crude protein) and isoenergetic (3,200 kcal $\mathrm{kg}^{-1}$ ) experimental diets were formulated, with a 5\% inclusion level of poultry hydrolysate protein (PHF), or swine liver hydrolysate protein (PHS), or feather hydrolysate protein (PHP) and a control treatment containing $5 \%$ of fishmeal (FPE). Four juveniles $(2.9 \pm 0.01 \mathrm{~g})$ were distributed in $10 \mathrm{~L}$ tanks and fed four times a day, and before each feeding event, diets were drawn. The same amount of pellets from each diet was offered, and feeding behaviors were recorded during three minutes for each feeding event, referred to the time of capture of the first pellet, number of pellet rejections, and number of approximations without capturing pellets and quantity of consumed pellets. A significant effect $(P<0.05)$ was observed regarding a higher consumption of pellets and palatability index for PHF, followed by PHS, FPE, and PHP. Therefore, it was concluded that PHF provided the highest compelling palatability for Nile tilapia juveniles, by displaying a $10.82 \%$ increase of the palatability index, $17 \%$ of final feed consumption, and presented a rejection number 6.89 times lower than FPE.
\end{abstract}

Keywords: Oreochromis niloticus; feed attractant; palatability agent; nutrition; behavior; aquaculture

Nile tilapia Oreochromis niloticus is a well-adapted species that inhabits several regions of the world, especially in places with tropical and subtropical climatic conditions, which are considered favorable for its adaptability, rearing and good performance (Higuchi et al., 2013; Brito et al., 2017).

In intensive fish farms, feed usually represents high operational costs, reaching up to $70 \%$ of the total expenses (Crivelenti et al., 2006; Furuya, 2010), with protein is the most expensive ingredient of feeds, whilst is the principal nutrient related to a fish's growth (Boscolo et al., 2005; Tacon \& Metian, 2008; Furuya, 2010; NRC, 2011; Zho \& Yue, 2012). One way of reducing costs with commercial feeds is reducing the use or completely replacing fishmeal, but a significant obstacle concerning this alternative is the acceptability of different ingredients by the animals, seen that diets rich in fishmeal has a well-known acceptance due to its high palatability (Kotzamanis et al., 2007).
The hydrolysis process is a chemical reaction performed with the addition of specific enzymes that modify the functional properties of raw materials when added, thus promoting protein breakdown in amino acids and peptides of multiple sizes, with high protein levels and digestibility (Ronnestad et al., 2007; Fries et al., 2011). This process provides the cleavage of proteins, resulting in nitrogen compounds of low molecular weight, which may act as attractive feeding substances since they are detected by the fish's gustatory system (Halver \& Hardy, 2002; Broggi et al., 2017).

Research shows that diets containing fish-based hydrolysate proteins blended with other animal's processing wastes, even in low levels, have been presenting positive effects on productive performance, immune system activities and digestibility in the first developmental stages of several species (Chotikachinda et al., 2013; Ovissipour et al., 2014; Srichanun et al.,

Corresponding editor: Fernando Vega-Villasante 
2014; Silva et al., 2017). Therefore, the present study was designed to determine the compelling palatability of poultry hydrolysate protein (PHF), swine liver hydrolysate protein (PHS), and feather hydrolysate protein (PHP) for Nile tilapia.

The essay was performed in the Laboratory of Aquaculture of the Aquaculture Management Study Group - GEMAq, of the University of West Paraná (UNIOESTE), Campus Toledo, PR, Brazil, from September 2016 to January 2017. The procedures used in the present study were approved by the Ethics Committee on Animal Use (CEUA) of the State University of West Paraná, according to Experimental Certificate of Animal Use No $45 / 17$.

Four isoproteic ( $30 \%$ crude protein, CP) and isoenergetic $\left(3,200 \mathrm{kcal} \mathrm{kg}^{-1}\right)$ experimental diets were formulated, according to the nutritional recommendations proposed by Furuya (2010). The three hydrolysates diets were produced and supplied by the company BRF Ingredients. The hydrolysates were made through a process of enzymatic hydrolysis in one of the factories of the company in Concórdia-SC, Brazil. The evaluated diets were: FPE (control) $=$ diet with a $5 \%$ inclusion level of fishmeal; PHF = diet with $5 \%$ inclusion level of poultry hydrolysate protein; PHS $=$ diet with $5 \%$ inclusion level of swine liver hydrolysate protein; and PHP = diet with 5\% inclusion level of feather hydrolysate protein (Table 1).

Ingredients were grounded and sieved $(0.3 \mathrm{~mm})$ in a hammer type mill previously to diets' formulation. For the extrusion of diets, blends were moistened with $20 \%$ of water and homogenized, then placed in a mechanical mixer type "Y" for $15 \mathrm{~min}$. The diets were extruded $(1.0 \mathrm{~mm})$ in an equipment model Ex-Micro, which holds a capacity of $10 \mathrm{~kg} \mathrm{~h}^{-1}$. After extrusion, all diets were dried in a forced ventilation oven for $24 \mathrm{~h}$ $\left(55^{\circ} \mathrm{C}\right)$.

Four juveniles with a mean weight of $2.9 \pm 0.01 \mathrm{~g}$ were placed in four aquariums $(10 \mathrm{~L})$ individually coated with a waterproofing latex material and equipped with aeration systems and temperature control by using $15 \mathrm{~W}$ thermostats. Each aquarium had a transparent lid with a centralized hole for pellets' addition.

Throughout the experiment, water temperature, $\mathrm{pH}$ and dissolved oxygen were, respectively: $25.12 \pm$ $1.15^{\circ} \mathrm{C}, 6.68 \pm 0.26$ and $4.55 \pm 0.64 \mathrm{mg} \mathrm{L}^{-1}$, being following the recommended by Ridha \& Cruz (2011) for the species' development. A polystyrene barrier was placed around the aquariums, isolating them from the laboratory routine, thus minimizing possible effects on the animals' behavior.
All four fish underwent an adaptation and training 15 days, so they would adapt to human presence during feeding events, where behaviors were registered, and the number of pellets was counted, until apparent satiety. At this time, fish were fed a commercial diet containing $40 \% \mathrm{CP}$, and its pellets were $1 \mathrm{~mm}$. After the adaptation period, the essay was initiated.

Fish were fed four times a day at 8,11,14 and $17 \mathrm{~h}$. Daily, all aquariums were siphoned to remove feces and food scraps. In feeding events, each fish received 20 pellets of the diet. The experimental design was completely randomized, with four replicates per day. A draw for each diet was daily performed for each fish, and a 3 min filming period was set with a camera (model BE Unique 4K Ultra HD) when the pellets were introduced in the aquariums. The essay lasted for eight days, and 128 footages were obtained ( 4 fish $\times 4$ feedings, 16 essays per day), and for each tested feed, 32 essays were performed.

The essays were performed based on the methodology described by several authors (Kasumyan \& Morsi, 1996; Kasumyan \& Doving, 2003; Kasumyan \& Sidorov, 2012). These authors proposed the palatability index as a quantitative estimate of taste preference (in percentage), using the following calculation: $\mathrm{IP}=((\mathrm{R}-\mathrm{C}) /(\mathrm{R}+\mathrm{C})) \times 100$, in which IP is the palatability index, $\mathrm{R}$ refers to pellet consumption of the tested feed and $\mathrm{C}$ is the pellet consumption of the control diet.

After data collection, all footages were examined, and the following feeding behaviors were analyzed: a) capture the first pellet (seconds), b) rejections of the pellet after capture, c) approaches without capturing pellets, and d) the number of consumed pellets. The palatability index was calculated for each treatment. The data were submitted to parametric variance analysis (ANOVA), and in case of significant effect ( $P$ $<0.05$ ), the Tukey's multiple comparison test was performed at a 5\% significance level. Before all analyses, the errors normality (Shapiro-Wilk) and homogeneity of variances (Levene's test) were verified. All statistical evaluations were performed with the aid of the software Statistic 7.1 (2005).

Significant differences were observed $(P<0.05)$ in pellets consumption and number of rejections after capture (Table 2). The PHF presented higher compelling palatability, with its palatability index being $10.82 \%$, higher than PHS (8.73\%) and PHP (-6.66\%), in comparison to the diet containing FPE. The mean value of pellet consumption referred to the PHF treatment was higher $(P<0.05)$ in comparison to PHP, but equal to the others $(P>0.05)$. An increase of $17 \%$ on pellets consumption was observed in PHF in relation to FPE. PHP provided the lowest consumption. 
Table 1. Composition of experimental diets used in the evaluation of compelling palatability with Nile tilapia (Oreochromis niloticus). ${ }^{1}$ Crude protein content. ${ }^{2}$ Guarantee levels per kilogram of the product: vit. A - 500,000 UI; vit. $\mathrm{D}_{3}-200,000 \mathrm{UI}$; vit. E - 5,000 mg; vit. $\mathrm{K}_{3}-1,000 \mathrm{mg}$; vit. $\mathrm{B}_{1}-1,500 \mathrm{mg}$; vit. $\mathrm{B}_{2}$ - 1,500 mg; vit. $\mathrm{B}_{6}$ - 1,500 mg; vit. $\mathrm{B}_{12}-4,000 \mathrm{mg}$; folic acid - $500 \mathrm{mg}$; calcium pantothenate - 4,000 mg; vit. C - 15,000 mg; biotin - $50 \mathrm{mg}$; inositol - 10,000 mg; nicotinamide 7,000 mg; choline - 40,000 mg; cobalt - $10 \mathrm{mg}$; copper - $500 \mathrm{mg}$; iron - 5,000 mg; iodine - $50 \mathrm{mg}$; manganese - 1,500 mg; selenium - $10 \mathrm{mg}$; zinc $-5,000 \mathrm{mg} .{ }^{3}$ Butil-hidroxi-toluene.

\begin{tabular}{|c|c|c|c|c|}
\hline \multirow[b]{2}{*}{ Ingredients } & \multicolumn{4}{|c|}{ Treatments } \\
\hline & $\begin{array}{l}\text { Fishmeal } \\
\text { (Control) }\end{array}$ & $\begin{array}{c}\text { Swine liver } \\
\text { hydrolysate protein }\end{array}$ & $\begin{array}{c}\text { Feather hydrolysate } \\
\text { protein }\end{array}$ & $\begin{array}{l}\text { Poultry hydrolysate } \\
\text { protein }\end{array}$ \\
\hline Soy bran $(45 \%)^{1}$ & 52.20 & 50.74 & 49.82 & 50.47 \\
\hline Maize $(8.5 \%)^{1}$ & 21.88 & 22.62 & 22.20 & 22.85 \\
\hline Rice grits $(8.5 \%)^{1}$ & 10.00 & 10.00 & 10.00 & 10.00 \\
\hline Wheat bran $(15.6 \%)^{1}$ & 5.00 & 5.00 & 5.00 & 5.00 \\
\hline Fishmeal $(55 \%)^{1}$ & 5.00 & 0.00 & 0.00 & 0.00 \\
\hline Swine liver hydrolysate protein $(70 \%)^{1}$ & 0.00 & 5.00 & 0.00 & 0.00 \\
\hline Feather hydrolysate protein $(79 \%)^{1}$ & 0.00 & 0.00 & 5.00 & 0.00 \\
\hline Poultry hydrolysate protein $(72 \%)^{1}$ & 0.00 & 0.00 & 0.00 & 5.00 \\
\hline Soybean oil & 3.08 & 2.66 & 3.97 & 2.72 \\
\hline Dicalcium phosphate & 1.34 & 1.99 & 2.02 & 1.91 \\
\hline Mineral-vitamin supplement & 0.50 & 0.50 & 0.50 & 0.50 \\
\hline Calcitic lime & 0.35 & 0.85 & 0.83 & 0.90 \\
\hline Salt & 0.30 & 0.30 & 0.30 & 0.30 \\
\hline Choline chloride $(60 \%)$ & 0.10 & 0.10 & 0.10 & 0.10 \\
\hline Antifungal (Calcium propionate) & 0.10 & 0.10 & 0.10 & 0.10 \\
\hline Vitamin C $(35 \%)$ & 0.10 & 0.10 & 0.10 & 0.10 \\
\hline Antioxidant $(\mathrm{BHT})^{3}$ & 0.02 & 0.02 & 0.02 & 0.02 \\
\hline Total & 100.00 & 100.00 & 100.00 & 100.00 \\
\hline \multicolumn{5}{|l|}{ Calculated Values } \\
\hline Starch $(\%)$ & 29.19 & 29.47 & 29.09 & 29.58 \\
\hline Calcium $(\%)$ & 1.00 & 1.00 & 1.00 & 1.00 \\
\hline Digestible energy $\left(\mathrm{kcal} \mathrm{kg}^{-1}\right)$ & 3,200 & 3,200 & 3,200 & 3,200 \\
\hline Total phosphorus (\%) & 0.80 & 0,80 & 0.80 & 0.80 \\
\hline Fat $(\%)$ & 5.52 & 5.12 & 6.08 & 5.02 \\
\hline Crude protein $(\%)$ & 30.00 & 30.00 & 30.00 & 30.00 \\
\hline
\end{tabular}

Significant differences were observed in the feeding behavior referred to the number of rejections after capture $(P<0.05)$. The lowest mean value of this variable was observed in PHF, with 0.29 pellets, followed by PHS with 1.15 pellets, while the highest rejection rate was observed in PHP, with 3.12 pellets. However, no differences were verified between FPE, PHF and PHS $(P>0.05)$, but the data allows the observation that PHF presented several pellet rejections 6.89 times higher about FPE. Approximations without capturing pellets were 0.43 for PHF, 0.62 for PHS, 1.00 for FPE and 1.37 for PHP.

Although this study did not focus on the chemical composition of the ingredients, it should be stressed that free amino acids were already studied and evaluated as feed stimulants (Table 3). The feed's amino acid composition was assessed by the method MA-009 (White et al., 1986; Hagen et al., 1989) at a commercial laboratory (CBO Laboratory Analysis Ltda., Valinhos-SP).
The differences found for the palatability index, pellets consumption and number of rejections after capture for PHF might be related to the content of amino acids present in protein hydrolysates coming from by-products of the poultry industry (Oliveira et al., 2014), seen that PHF presented a higher amino acid content in comparison to PHS and PHP (Table 3). Amino acids are essential components for a diet's palatability since they send chemical signs to the animal's gustatory system. The presence of free amino acids and peptides of low molecular weight is important for a diet's palatability (Naylor et al., 2009; Kasumyan \& Doving, 2003; NRC, 2011).

Concerning the feeding behavior referred to the time of capture of the first pellet, no differences were observed $(P<0.05)$ (Table 2). However, it was verified that for all diets, fish rapidly captured pellets, showing no rejection. The rapid pursuit for feed is one of the stages of the feeding behavior that may be stimulated by using ingredients in the diet with good tractability. When stimulating the extraoral taste response of the 
Table 2. Mean values of the compelling palatability test of different protein hydrolysates for Nile tilapia (Oreochromis niloticus), compared to fishmeal (control). Means followed by distinct letters within columns indicate significant differences by the Tukey's test $(P<0.05)$.

\begin{tabular}{|c|c|c|c|c|c|}
\hline Treatments & $\begin{array}{l}\text { Palatability } \\
\text { index }(\%)\end{array}$ & $\begin{array}{c}\text { Pellets } \\
\text { consumption }(\%)\end{array}$ & $\begin{array}{l}\text { Number of rejection } \\
\text { of pellets after capture }\end{array}$ & $\begin{array}{c}\text { Number of approximations } \\
\text { without capturing } \\
\text { pellets }\end{array}$ & $\begin{array}{c}\text { Time for the capture } \\
\text { of the first pellet } \\
\text { (seconds) }\end{array}$ \\
\hline Control & 0 & $83.64 \pm 22.03^{\mathrm{ab}}$ & $2.00 \pm 2.09^{\mathrm{ab}}$ & $1.00 \pm 1.34$ & $0.87 \pm 0.45$ \\
\hline Poultry hydrolysate protein & 10.82 & $97.86 \pm 5.67^{\mathrm{a}}$ & $0.29 \pm 0.75^{b}$ & $0.43 \pm 0.78$ & $0.85 \pm 0.39$ \\
\hline Swine liver hydrolysate protein & 8.73 & $89.37 \pm 18.21^{\mathrm{ab}}$ & $1.15 \pm 2.10^{\mathrm{ab}}$ & $0.62 \pm 1.06$ & $0.68 \pm 0.42$ \\
\hline Feather hydrolysate protein & -6.66 & $74.37 \pm 26.38^{\mathrm{b}}$ & $3.12 \pm 2.99^{\mathrm{a}}$ & $1.37 \pm 1.84$ & $0.92 \pm 0.45$ \\
\hline
\end{tabular}

Table 3. Free amino acids of the protein hydrolysates used in the evaluation of compelling palatability for Nile tilapia (Oreochromis niloticus).

\begin{tabular}{lccc}
\hline Chemical Composition & $\begin{array}{c}\text { Poultry hydrolysate } \\
\text { protein }(\%)\end{array}$ & $\begin{array}{c}\text { Swine liver hydrolysate } \\
\text { protein }(\%)\end{array}$ & $\begin{array}{c}\text { Feather hydrolysate } \\
\text { protein }(\%)\end{array}$ \\
\hline Aspartic acid & 0.81 & 0.45 & 0.04 \\
Glutamic acid & 1.11 & 1.05 & 0.10 \\
Serine & 0.56 & 0.40 & 0.02 \\
Glycine & 0.36 & 0.18 & Undetected \\
Histidine & 0.23 & 0.42 & 0.17 \\
Taurine & 0.36 & 0.08 & 0.05 \\
Arginine & 1.42 & 0.24 & 0.03 \\
Threonine & 0.66 & 0.56 & 0.10 \\
Alanine & 1.08 & 1.08 & 0.05 \\
Proline & 0.49 & 0.46 & 0.06 \\
Tyrosine & 1.01 & 0.49 & 0.10 \\
Valine & 1.17 & 0.89 & 0.11 \\
Methionine & 0.79 & 0.27 & 0.10 \\
Cystine & 0.16 & 0.15 & Undetected \\
Isoleucine & 0.91 & 0.60 & 0.14 \\
Leucine & 1.91 & 1.54 & 0.13 \\
Phenylalanine & 0.97 & 0.67 & 0.08 \\
Lysine & 1.36 & 0.86 & 0.03 \\
Asparagine & Undetected & 0.40 & 0.02 \\
Glutamine & Undetected & 0.18 & Undetected \\
\hline Total & 15.36 & 10.97 & 1.33 \\
\hline
\end{tabular}

animal, one triggers the behavior of searching for food (Kasumyan \& Doving, 2003). The rapid capture is desirable in aquaculture, seen that it may reflect in lower losses of nutrients to the water, resulting in complete ingestion of the balanced diet, thus causing less environmental impact (Cyrino et al., 2010).

The feeding stimulants that presented higher consumption percentages were PHF and PHS. When studying poultry viscera meal as attractants for Nile tilapia juveniles, Boscolo et al. (2001) also observed satisfactory results. Swine liver, tilapia carcass, and sardine hydrolysates were evaluated in the diet of Iguaçu surubim Steindachneridion melanodermatum and Rhamdia quelen by Lewandowski et al. (2013) and Decarli et al. (2016). These authors highlighted that, in comparison to their control treatments, the swine liver hydrolysate provided the greatest results of weight gain, the final length of fish and feed conversion.

The process of enzyme hydrolysis produces free amino acids and peptides that besides improving diet's acceptance by fish, may improve its performance and health because during the enzymatic hydrolysis many bioactive peptides are formed (Kotzamanis et al., 2007). Therefore, PHF and PHS have great potential in aquaculture. However, it is understood that more studies are necessary in order to evaluate the potential of hydrolysates in the improvement of performance and health status.

The PHF flavoring increased palatability index and final feed consumption and provided the lower rejec- 
tion of pellets, as well as a lower number of approximations without capturing the pellets in relation to the control diet containing fishmeal. Therefore, it can be efficiently used to stimulate the consumption of feed for Nile tilapia juveniles with fishmeal are replaced.

\section{ACKNOWLEDGMENTS}

The authors thank the company BRF Ingredients for the donation of ingredients, and the Aquaculture Management Study Group-GEMAq, of the University of West Paraná-UNIOESTE, Campus Toledo/PR, for the availability of laboratory studies and technical support.

\section{REFERENCES}

Boscolo, W.R., Hayashi, C., Meurer, F. \& Soares, C.M. 2001. Farinhas de peixe, carne e ossos, vísceras e crisálida como atractantes em dietas para alevinos de tilápia do Nilo Oreochromis niloticus. Revista Brasileira de Zootecnia, 30(5): 1397-1402.

Boscolo, W.R., Hayashi, C., Meurer, F., Feiden, A., Bombardelli, R.A. \& Reidel, A. 2005. Farinha de resíduos da filetagem de tilápias na alimentação de tilápia do Nilo Oreochromis niloticus. Revista Brasileira de Zootecnia, 34(6): 1807-1812.

Brito, J.M., Pontes, T.C., Tsujii, K.M., Araújo, F.E. \& Ricther, B.L. 2017. Automação na tilapicultura: revisão de literatura, desempenho, piscicultura, tecnologias, tilápias. Nutritime, 14(3): 5053-5062.

Broggi, J.A., Wosiak, B., Uczay, J., Pessatti, M.L. \& Fabregat, T.E.H.P. 2017. Hidrolisado proteico de resíduo de sardinha como atrativo alimentar para juvenis de jundiá. Arquivo Brasileiro de Medicina Veterinária e Zootecnia, 69(2): 505-512.

Cyrino, J.E.P., Bicudo, A.J.A., Sado, R.Y., Borghesi, R. \& Dairiki, J.K. 2010. A piscicultura e o ambiente - o uso de alimentos ambientalmente corretos em piscicultura. Revista Brasileira de Zootecnia, 39: 68-87.

Chotikachinda, R., Tantikitti, C., Benjakul, S., Rustad, T. \& Kumarnsit, E. 2013. Production of protein hydrolysates from skipjack tuna Katsuwonus pelamis viscera as feeding attractants for Asian seabass Lates calcarifer. Aquaculture Nutrition, 19(5): 773-784.

Crivelenti, L.Z., Borin, S., Pirtouscheg, A., Neves, J.E.G. \& Abdão, E.M. 2006. Desempenho econômico da criação de tilápias do Nilo Oreochromis niloticus em sistema de produção intensiva. Veterinária Noticias, 2(12): 117-122.

Decarli, J.A., Pedron, F.A., Lazzari, R., Signor, A., Boscolo, W.R. \& Feiden, A. 2016. Hidrolisados proteicos na alimentação do jundiá Rhamdia voulezi. Revista Brasileira de Ciencias Veterinarias, 23(3-4): 168-173.
Fries, E.M., Luchesi, J.D., Costa, J.M., Ressel, C., Signor, A.A., Boscolo, W.R. \& Feiden, A. 2011. Hidrolisados cárneos proteicos em rações para alevinos de Kinguio Carassius auratus. Boletim do Instituto de Pesca, 37(4): 401-407.

Furuya, W.M. 2010. Tabelas brasileiras para a nutrição de tilápias. GFM Gráfica e Editora Ltda., Toledo.

Hagen, S.R., Frost, B. \& Augustin, J. 1989. Precolumn phenylsothiocyanate derivatization and liquidchromatography of amino-acids in food. Journal of the Association of Official Analytical Chemists, 72(6): 912-916.

Halver, J.E. \& R.W. Hardy. 2002. Fish nutrition. Elsevier Science, San Diego.

Higuchi, L.H., Feiden, A., Matsushita, M., Santarosa, M., Zanqui, A.B., Bittencourt, F. \& Boscolo, W.R. 2013. Quantificação de ácidos graxos de alevinos de tilápia do Nilo (Oreochromis niloticus) alimentados com diferentes fontes de óleos vegetais. Semina: Ciências Agrárias, 34(4): 1913-1924.

Kasumyan, A.O. \& Morsi, A.M. 1996. Taste sensitivity of common carp Cyprinus carpio to free amino acids and classical taste substances. Journal of Ichthyology, 36(5): 391-403.

Kasumyan A.O. \& Doving, K.B. 2003. Taste preferences in fish. Fish and Fisheries, 4(4): 289-347.

Kasumyan, A.O. \& Sidorov, S.S. 2012. Effects of the long-term anosmia combined with vision deprivation on the taste sensitivity and feeding behavior of the rainbow trout Parasalmo (=Oncorhynchus) mykiss. Journal of Ichthyology, 52(1): 109-119.

Kotzamanis, Y.P., Gisbert, E., Gatesoupe, F.J., Infante, J.Z. \& Cahu, C. 2007. Effects of different dietary levels of fish protein hydrolysates on growth, digestive enzymes, gut microbiota, and resistance to Vibrio anguillarum in European sea bass Dicentrarchus labrax larvae. Comparative Biochemistry and Physiology, Part A: Molecular \& Integrative Physiology, 147(1): 205-214.

Lewandowski, V., Decarli, J.A., Pedrn, F.A., Feiden, A., Signor, A. \& Boscolo, W.R. 2013. Hidrolisados cárneos na alimentação do surubim do Iguaçu Steindachneridion melanodermatum. Revista Brasileira de Ciencias Veterinarias, 20(4): 222-226.

Naylor, R.L., Hardy, R.W., Bureau, D.P., Chiu, A., Elliott, M., Farrel, A.P., Forster, I., Gatlin, D.M., Goldburg, R.J., Hua, K. \& Nichols, P.D. 2009. Feeding aquacultures in an era of finite resources. Proceedings of the National Academy of Sciences of the United States of America, 106(36): 15103-15110.

National Research Council (NRC). 2011. Nutrient requirements of fish and shrimp. National Academies Press, Washington. 
Oliveira, M.S.R., Franzen, F.L. \& Terra, N.N. 2014 Utilização da carne mecanicamente separada de frango para a produção de hidrolisados proteicos a partir de diferentes enzimas proteolíticas. Semina: Ciências Agrárias, 35(1): 291-302.

Ovissipour, M., Kenari, A.A., Nazari, R., Motamedzadegan, A. \& Rasco, B. 2014. Tuna viscera protein hydrolysate: nutritive and disease resistance properties for Persian sturgeon Acipenser persicus L. larvae. Aquaculture Research, 45(4): 591-601.

Ronnestad, I., Kamisaka, Y., Conceição, L.E.C., Morais, S. \& Tonheim, S.K. 2007. Digestive physiology of marine fish larvae: hormonal control and processing capacity for proteins, peptides and amino acids. Aquaculture, 268(1): 82-97.

Ridha, M.T. \& Cruz, E.M. 2001. Effect of biofilter media on water quality and biological performance of the tilápia Oreochromis niloticus L. reared in a simple recirculating system. Aquacultural Engineering, 24(2): 157-166.

Silva, T.C., Rocha, J.D.M., Moreira, P., Signor, A. \& Boscolo, W.R. 2017. Fish protein hydrolysate in diets for Nile tilapia post-larvae. Pesquisa Agropecuária Brasileira, 52(7): 485-492.

Received: 25 September 2018; Accepted: 3 December 2018
Srichanun, M., Tantikiti, C., Kortner, T.M., Krogdahn, A. \& Chotikachinda, R. 2014. Effects of different protein hydrolysate products and levels on growth, survival rate and digestive capacity in Asian seabass Lates calcarifer Bloch larvae. Aquaculture, 428-429: 195202.

Tacon, A.G.F. \& Metian, M. 2008. Global overview on the use of fish meal and fish oil in industrially compounded aquafeeds: trends and prospects. Aquaculture, 285(1-4): 146-158.

Zhou, Q.C. \& Yue, Y.R. 2012. Apparent digestibility coefficients of selected feed ingredients for juvenile hybrid tilapia, Oreochromis niloticus x Oreochromis aureus. Aquaculture Research, 43(6): 806-814.

White, J.A., Hart, R.J. \& Fry, J.C. 1986. An evaluation of the Waters Pico-Tag system for the amino-acidanalysis of food materials. Australian Journal of Chemistry, 8(4): 170-177. 